\title{
Effect of UV protectants mixed with HaNPV on POBs and larval mortality of Helicoverpa armigera Hübner
}

\author{
P.N. Mane ${ }^{1^{*}}$, N.S. Satpute ${ }^{2}$, M.P. Moharil ${ }^{3}$, M.Y. Ladole', S.M. Thakare ${ }^{2}$ and \\ A.K. Gade ${ }^{4}$
}

\begin{abstract}
Baculovirus could be an attractive candidate for integrated pest management (IPM) because of its inherent high pathogenicity, narrow host range, and safety to vertebrates, plants and the environment. Despite these advantages, its practical application as a microbial pesticide has not been fully exploited due to rapid inactivation of the virus by sunlight (UV rays). However, additives can be used to protect the baculovirus from light degradation. The present study was carried out to test the potential of silver nanoparticles (SNPs) as UV protectants along with $1 \%$ Tinopal $^{\circledR}$ and $1 \%$ mango leaf extract, and to develop Helicoverpa armigera Nucleopolyhedrovirus (HaNPV)-ready formulation with potential UV protectant during 2012-2013. An attempt was also made to use SNPs as an antimicrobial additive to extend the shelf life of HaNPV and to shelter the polyhedral occlusion bodies (POBs) from UV degradation after spraying in field against $H$. armigera Hübner on various crops. Formulated viral suspensions were exposed to UV 20 W Philips lamp (Type 5, range 285 - 320 $\mathrm{nm}$ ) for $15 \mathrm{~min}$ and to sunlight at noon hours for $30 \mathrm{~min}$, and 1, 1.5 and 2 hrs to determine the viability of POBs and larvicidal activity. The least reduction in POBs i.e. $5.2 \%$, was observed from HaNPV + $1 \%$ Tinopal, which also recorded a $86.7 \%$ larval mortality when exposed to UV lamp. The results was in par ( $p>0.05)$ with HaNPV alone un-irradiated. The HaNPV alone with irradiation recorded $55.1 \%$ reduction in POBs, while HaNPV $+1 \%$ Tinopal with exposure to sunlight protected the POBs up to $1.5 \mathrm{hr}$, with $20.5 \%$ reduction in POBs and $83.9 \%$ larval mortality. Exposure to for 2 hrs reduced the insecticidal activity of HaNPV even though $1 \%$ Tinopal was used as a UV protectant. Of the additives, $1 \%$ Tinopal was found to be effective as it protected the POBs from UV degradation and enhanced the larval mortality as compared to $1 \%$ mango leaf extract and SNPs.
\end{abstract}

Keywords: Silver nanoparticles, HaNPV, UV protectant, Tinopal ${ }^{\circledR}$

\section{Introduction}

Helicoverpa armigera Hübner (Lepidoptera: Noctuidae) is a highly polyphagous and widespread insect pest, inflicting an annual crop damage worth US \$ 1 billion in India. Although nearly $30 \%$ of total insecticides were used to control this pest alone on different crops, many of those insecticides were not effective probably due to the development of insecticide-resistance at varying degrees (Yaqoob et al., 2006).

\footnotetext{
1 Oilseeds Research Unit, ${ }^{2}$ Department of Entomology, ${ }^{3}$ Biotechnology Centre Dr. Panjabrao Deshmukh Krishi Vidyapeeth, Krishinagar, Akola, Maharashtra, India

4 Department of Biotechnology, Sant Gadgebaba University, Amravati, Maharashtra, India.

* Corresponding author: pnmane_ento@rediffmail.com
} 
Chemical insecticide use is also becoming less appropriate due to concerns on consumer food safety and the environment, especially being incompatible with the pollinators. Therefore, the demand in the present day scenario is for the ecofriendly means of pest control, and among them, the insect viruses are of immense utility.

Baculovirus could be an attractive candidate for integrated pest management (IPM) due to its inherent high pathogenicity, narrow host range, and safety to vertebrates, plants and the environment. Despite these advantages, their practical application as microbial pesticides has not been fully exploited. Among the limiting factors, rapid inactivation of the virus by sunlight (UV light) is probably the most important factor affecting the persistence of microbial insecticides. The UV radiation directly affects the nucleic acids, modifying or denaturing them, preventing growth and reproduction of the microorganism. However, additives can be used to protect the baculovirus from these factors. The silver nanoparticles (SNPs) are potent and broad-spectrum antimicrobial agents, and express a significant UV protection capability (Vigneshwaran et al., 2007). Tinopal and optical brighteners may protect the virus from solar radiation increasing the susceptibility of pests to viral infection (Burges and Jones. 1998). Polyflavonoids from mango leaves has also being reported to protect NPV from inactivation by sunlight (Asokan, 1998). In this study, additives such as (SNPs) at different concentration, Tinopal and mango (Mangifera indica L.) leaf extract were evaluated as potent UV protectants to be used as an additive in $H$. armigera Nucleopolyhedrovirus (HaNPV)-ready formulation.

\section{Materials and Methods}

The study was carried out in randomized complete block design with three replicates at the Department of Entomology, Dr. Panjabrao Deshmukh Krishi Vidyapeeth, Akola, Maharashtra, India during 2011 - 2013. Formulated viral suspensions were exposed to $20 \mathrm{~W}$ UV lamp (Type 5, range 285-320 nm UV radiation) for $15 \mathrm{~min}$. For sunlight exposure, $2 \mathrm{ml}$ of required concentration of HaNPV formulation was kept in Petri plates and exposed to sunlight during the noon time for $30 \mathrm{~min}$, and 1, 1.5 and $2 \mathrm{hrs}$. The polyhedral occlusion bodies (POB) count of the viral formulations before and after UV and sunlight exposure was determined by using Neubauer Haemocytometer, and the larvicidal activity was tested against second instar larvae of $\mathrm{H}$. armigera. Before testing the viability and larvicidal activity of irradiated samples, the volume of each sample was adjusted with sterile distilled water to compensate for the loss of water due to evaporation. For the larvicidal activity, $50 \mu \mathrm{l}$ of the HaNPV formulation exposed to UV lamp and sunlight over the half-broken soaked chickpea (Cicer arietinum L.) grain was used on 30 laboratoryreared second instar larvae of $H$. armigera in each treatment (Tables 1 and 2 ). 
The mango leaf extract prepared by extracting dried, powdered mango leaves using methanol (powder/solvent ratio 1:10 w/v), and by maceration at room temperature. After 24 hrs of extraction, the sample was filtered through Whatman number 1 filter paper and the same plant material was extracted again with another $1000 \mathrm{ml}$ of methanol. This procedure was repeated for three days. Thereafter, the methanol extracts were combined and evaporated to dryness. The dry extracts were re-suspended in distilled water at concentration of $20 \mathrm{mg} / \mathrm{ml}$ and this stock solution. A $1 \%$ extract of this stock solution was made in HaNPV. Tinapol ${ }^{\circledR}$ was used as a $1 \%$ solution in HaNPV. The silver nanoparticles (SNPs) obtained from the Department of Biotechnology, Sant Gadge Baba Amravati University, Maharashtra, India were applied at different concentration in HaNPV, i.e. at 10, 20,30, 50 and $80 \mathrm{ul} / \mathrm{ml}$ of HaNPV.

Larvae were starved for 24 hrs before being released. Fresh, soaked chickpea grain was used for further feeding. The larval mortality was scored at 3 days after treatment up to the $10^{\text {th }}$ day. Mortality caused at $10^{\text {th }}$ day after treatment was analyzed using ANOVA after arc sin transformation. The \% mortality was corrected by using Abbots formula.

\section{Results and Discussion}

Tables 1 and 2 revealed that the least reduction in POBs was from HaNPV $+1 \%$ Tinopal, recording the highest larval mortality when exposed to UV lamp. This was followed by HaNPV + $1 \%$ mango leaf extract. The HaNPV + SNPs at $80 \mu \mathrm{l} / \mathrm{ml}$ of HaNPV, protected the POBs and reduced $45.6 \%$ of larval population. The HaNPV alone with irradiation recorded the maximum reduction in $\mathrm{POBs}$ and the lowest larval mortality. However, the HaNPV $+1 \%$ Tinopal recorded lowest reduction in POBs and highest larval mortality \%, when exposed to natural sunlight for $30 \mathrm{~min}$, and 1 and $1.5 \mathrm{hrs}$. The $2 \mathrm{hr}$ sunlight exposure recorded the highest reduction in POBs and lower larval mortality compared other periods of exposure, followed by HaNPV $+1 \%$ mango leaf extract $1 \%$, and $\mathrm{HaNPV}+\mathrm{SNP}$ at $80 \mu \mathrm{l} / \mathrm{ml}$ of HaNPV.

The formulated HaNPV having $1 \%$ Tinopal as a UV protectant remained viable in 285-320 $\mathrm{nm}$ UV radiation up to $15 \mathrm{~min}$ and in sunlight at noon time up to $1.5 \mathrm{hrs}$, however, the insecticidal activity started reducing thereafter at prolonged exposure. The HaNPV was progressively inactivated as the exposure time to UV source increased. Tinopal would absorb long wave UV light and there by providing protection to $\mathrm{POBs}$ from inactivation. Several optical brighteners are known to interfere with cellulose and chitin fibrillogenesis. Optical brighteners increase the permeability of the midgut peritrophic membrane and reduce the rate of turnover of infected gut cells (Burges and Jones. 1998). . This may have spread the infection more rapidly to the susceptible tissues that are involved in the secondary cycle of infection thus, accounting for early larval mortality. 
Mane et al.

Table 1. Effect of HaNPV with UV protectants with exposure to UV rays and sunlight on POBs

\begin{tabular}{|c|c|c|c|c|c|}
\hline \multirow{3}{*}{ Treatments } & \multicolumn{5}{|c|}{ Per cent reduction in POBs (pooled mean) } \\
\hline & \multirow{2}{*}{$\begin{array}{c}\text { Duration of } \\
\text { UV } \\
\text { Exposure } \\
(15 \mathrm{~min}) \\
\end{array}$} & \multicolumn{4}{|c|}{ Duration of sunlight exposure } \\
\hline & & $30 \mathrm{~min}$ & $1 \mathrm{hr}$ & $1.5 \mathrm{hrs}$ & $2 \mathrm{hrs}$ \\
\hline HaNPV + SNPs $(10 \mu \mathrm{l} / \mathrm{ml}$ of HaNPV $)$ & $\begin{array}{c}54.7 \\
(47.7)^{*}\end{array}$ & $\begin{array}{l}28.2 \\
(32.1)\end{array}$ & $\begin{array}{c}47.4 \\
(43.8)\end{array}$ & $\begin{array}{c}62.1 \\
(52.0)\end{array}$ & $\begin{array}{c}66.1 \\
(54.4)\end{array}$ \\
\hline HaNPV + SNPs $(20 \mu \mathrm{l} / \mathrm{ml}$ of HaNPV $)$ & $\begin{array}{c}52.8 \\
(46.6)\end{array}$ & $\begin{array}{c}26.4 \\
(30.9)\end{array}$ & $\begin{array}{c}44.9 \\
(42.3)\end{array}$ & $\begin{array}{c}59.9 \\
(50.7)\end{array}$ & $\begin{array}{c}59.0 \\
(50.2)\end{array}$ \\
\hline HaNPV + SNPs $(30 \mu \mathrm{l} / \mathrm{ml}$ of HaNPV) & $\begin{array}{c}52.5 \\
(46.5)\end{array}$ & $\begin{array}{c}26.3 \\
(30.9)\end{array}$ & $\begin{array}{c}42.6 \\
(40.4)\end{array}$ & $\begin{array}{c}58.4 \\
(49.8)\end{array}$ & $\begin{array}{c}57.1 \\
(49.1)\end{array}$ \\
\hline HaNPV + SNPs $(50 \mu \mathrm{l} / \mathrm{ml}$ of HaNPV) & $\begin{array}{c}50.4 \\
(45.2)\end{array}$ & $\begin{array}{c}20.6 \\
(27.0)\end{array}$ & $\begin{array}{c}37.3 \\
(37.7)\end{array}$ & $\begin{array}{c}56.9 \\
(49.0)\end{array}$ & $\begin{array}{c}56.1 \\
(48.5)\end{array}$ \\
\hline HaNPV + SNPs $(80 \mu \mathrm{l} / \mathrm{ml}$ of HaNPV $)$ & $\begin{array}{c}47.9 \\
(43.8)\end{array}$ & $\begin{array}{c}14.5 \\
(22.3)\end{array}$ & $\begin{array}{c}31.4 \\
(32.6)\end{array}$ & $\begin{array}{c}47.4 \\
(43.5)\end{array}$ & $\begin{array}{c}52.2 \\
(46.3)\end{array}$ \\
\hline HaNPV + $1 \%$ Tinopal $^{\circledR}$ & $\begin{array}{c}5.2 \\
(12.9)\end{array}$ & $\begin{array}{c}5.2 \\
(13.0)\end{array}$ & $\begin{array}{c}19.2 \\
(26.0)\end{array}$ & $\begin{array}{c}20.5 \\
(20.9)\end{array}$ & $\begin{array}{c}45.6 \\
(42.5)\end{array}$ \\
\hline HaNPV $+1 \%$ mango leaf extract & $\begin{array}{l}13.8 \\
(21.4)\end{array}$ & $\begin{array}{c}7.9 \\
(16.3)\end{array}$ & $\begin{array}{c}12.8 \\
(14.2)\end{array}$ & $\begin{array}{l}32.3 \\
(50.35)\end{array}$ & $\begin{array}{c}47.8 \\
(43.8)\end{array}$ \\
\hline HaNPV alone - irradiated & $\begin{array}{c}55.1 \\
(47.9)\end{array}$ & $\begin{array}{c}31.6 \\
(34.2)\end{array}$ & $\begin{array}{l}58.0 \\
(51.4)\end{array}$ & $\begin{array}{c}62.9 \\
(52.5)\end{array}$ & $\begin{array}{r}63.9 \\
(53.1)\end{array}$ \\
\hline HaNPV alone - Not-irradiated & $\begin{array}{c}2.9 \\
(9.1)\end{array}$ & $\begin{array}{c}1.2 \\
(6.4)\end{array}$ & $\begin{array}{c}7.8 \\
(11.0)\end{array}$ & $\begin{array}{c}7.8 \\
(16.1)\end{array}$ & $\begin{array}{c}3.3 \\
(10.3)\end{array}$ \\
\hline F-test & Sig & Sig & Sig & Sig & Sig \\
\hline $\mathrm{SE}( \pm)$ & 0.45 & 0.98 & 0.51 & 0.55 & 0.94 \\
\hline C.D. at $p=0.05$ & 1.31 & 2.89 & 1.51 & 1.62 & 2.7 \\
\hline C.V.\% & 2.08 & 2.93 & 2.04 & 2.23 & 4.53 \\
\hline
\end{tabular}

* Values in the parenthesis are arc sin transformed values; POBs=polyhedral occlusion bodies; HaNPV=Helicoverpa armigera Nucleopolyhedrovirus; SNPs=silver nanoparticles, SE=standard error of the mean; C.D.=critical difference

Optical brighteners such as Tinopal administered in mixtures with occlusion bodies would result in a higher prevalence of covert infection in larvae (Burges and Jones, 1998). Martinez et al. (2004) reported that $1 \%$ Tinopal concentration was sufficient to enhance the mortality and hasten the death of Spodoptera frugiperda (Lepidoptera: Noctuidae) larvae. The results revealed that $1 \%$ Tinopal effectively sheltered the POBs from UV degradation and enhanced larval mortality compared to $1 \%$ mango leaf extract $1 \%$ and SNPs. 
Table 2. Effect of UV rays and sunlight exposed HaNPV with UV protectants on larval mortality of $\mathrm{H}$. armigera

\begin{tabular}{|c|c|c|c|c|c|}
\hline \multirow{3}{*}{ Treatments } & \multicolumn{5}{|c|}{ Per cent larval mortality at 10 DAT (Pooled Mean) } \\
\hline & \multirow{2}{*}{$\begin{array}{l}\text { Duration } \\
\text { of UV } \\
\text { Exposure } \\
\text { (15 min) }\end{array}$} & \multicolumn{4}{|c|}{ Duration of sunlight exposure } \\
\hline & & $30 \mathrm{~min}$ & $1 \mathrm{hr}$ & $1.5 \mathrm{hrs}$ & $2 \mathrm{hrs}$ \\
\hline HaNPV + SNPs $(10 \mu \mathrm{l} / \mathrm{ml}$ of HaNPV) & $\begin{array}{c}13.9 \\
(21.8)^{*}\end{array}$ & $\begin{array}{l}77.8 \\
(61.9)\end{array}$ & $\begin{array}{c}38.3 \\
(38.3)\end{array}$ & $\begin{array}{c}38.3 \\
(38.3)\end{array}$ & $\begin{array}{c}13.9 \\
(21.9)\end{array}$ \\
\hline HaNPV + SNPs $(20 \mu \mathrm{l} / \mathrm{ml}$ of HaNPV $)$ & $\begin{array}{c}20.6 \\
(26.9)\end{array}$ & $\begin{array}{c}78.9 \\
(62.7)\end{array}$ & $\begin{array}{c}42.8 \\
(40.9)\end{array}$ & $\begin{array}{c}43.3 \\
(41.2)\end{array}$ & $\begin{array}{c}21.1 \\
(27.4)\end{array}$ \\
\hline $\mathrm{HaNPV}+\mathrm{SNPs} * 30 \mu \mathrm{l} / \mathrm{ml}$ of HaNPV) & $\begin{array}{c}23.9 \\
(29.3)\end{array}$ & $\begin{array}{c}78.9 \\
(62.7)\end{array}$ & $\begin{array}{c}46.1 \\
(42.8)\end{array}$ & $\begin{array}{c}48.3 \\
(44.0)\end{array}$ & $\begin{array}{c}28.9 \\
(32.5)\end{array}$ \\
\hline HaNPV + SNPs $(50 \mu \mathrm{l} / \mathrm{ml}$ of HaNPV $)$ & $\begin{array}{c}31.1 \\
(33.9)\end{array}$ & $\begin{array}{c}80.0 \\
(63.5)\end{array}$ & $\begin{array}{c}49.4 \\
(44.7)\end{array}$ & $\begin{array}{c}47.2 \\
(43.4)\end{array}$ & $\begin{array}{c}31.1 \\
(33.9)\end{array}$ \\
\hline HaNPV + SNPs $(80 \mu \mathrm{l} / \mathrm{ml}$ of HaNPV $)$ & $\begin{array}{c}42.8 \\
(40.9)\end{array}$ & $\begin{array}{c}81.1 \\
(64.3)\end{array}$ & $\begin{array}{c}50.0 \\
(45.0)\end{array}$ & $\begin{array}{c}50.6 \\
(45 \cdot 3)\end{array}$ & $\begin{array}{c}45.6 \\
(42.5)\end{array}$ \\
\hline HaNPV + Tinopal $1 \%$ & $\begin{array}{c}86.7 \\
(68.6)\end{array}$ & $\begin{array}{c}87.8 \\
(69.6)\end{array}$ & $\begin{array}{c}87.2 \\
(69.1)\end{array}$ & $\begin{array}{c}82.8 \\
(65.5)\end{array}$ & $\begin{array}{c}68.9 \\
(57.5)\end{array}$ \\
\hline HaNPV $+1 \%$ mango leaf extract & $\begin{array}{c}78.9 \\
(62.7)\end{array}$ & $\begin{array}{c}81.1 \\
(64.3)\end{array}$ & $\begin{array}{c}78.3 \\
(62.3)\end{array}$ & $\begin{array}{c}71.7 \\
(57.9)\end{array}$ & $\begin{array}{l}60.6 \\
(51.1)\end{array}$ \\
\hline HaNPV alone - irradiated & $\begin{array}{c}15.0 \\
(22.8)\end{array}$ & $\begin{array}{c}77.8 \\
(61.9)\end{array}$ & $\begin{array}{c}19.4 \\
(26.2)\end{array}$ & $\begin{array}{c}21.1 \\
(27.4)\end{array}$ & $\begin{array}{c}18.9 \\
(25.7)\end{array}$ \\
\hline HaNPV alone Not irradiated & $\begin{array}{c}82.8 \\
(65.5)\end{array}$ & $\begin{array}{c}84.4 \\
(66.9)\end{array}$ & $\begin{array}{c}83.3 \\
(65.9)\end{array}$ & $\begin{array}{c}83.9 \\
(66.3)\end{array}$ & $\begin{array}{c}84.4 \\
(66.8)\end{array}$ \\
\hline Control (Water) & $\begin{array}{c}0.0 \\
(0.5)\end{array}$ & $\begin{array}{c}0.0 \\
(0.5)\end{array}$ & $\begin{array}{c}0.0 \\
(0.5)\end{array}$ & $\begin{array}{c}0.0 \\
(0.5)\end{array}$ & $\begin{array}{c}0.0 \\
(0.5)\end{array}$ \\
\hline F Test & Sig & Sig & Sig & Sig & Sig \\
\hline $\mathrm{SE}( \pm)$ & 0.45 & 0.98 & 0.51 & 0.55 & 0.94 \\
\hline C.D. $p=0.05$ & 1.31 & 2.89 & 1.51 & 1.62 & 2.7 \\
\hline C.V.\% & 2.08 & 2.93 & 2.04 & 2.23 & 4.53 \\
\hline
\end{tabular}

* Values in the parenthesis are arc sin transformed values; DAT=days after treatment; HaNPV=Helicoverpa armigera Nucleopolyhedrovirus; SNPs=silver nanoparticles, SE=standard error of the mean; C.D.=critical difference

\section{Conclusion}

Tinopal $^{\boxplus}(1 \%)$ is an effective UV protectant and can be used as an additive for developing HaNPV formulations (a biopesticide) for the control of the H. armigera. Higher concentration of SNPs i.e. $80 \mu \mathrm{l} / \mathrm{ml}$ of HaNPV, shelters degradation of POBs with different times of exposure to sun light would result in a relatively higher larval mortality of the insect pest, show bactericidal property, avoid contamination and extend the shelf life of HaNPV. 


\section{Acknowledgement}

Authors are thankful to the Head, Department of Entomology, Dr. Panjabrao Deshmukh Krishi Vidyapeeth, Akola for providing the facilities for carried out the research work.

\section{References}

Asokan, R. (1998): Plant derived polyflavonoids as sunscreens for nuclear polyhedrosis viruses. Insect Environ. 4 (3): 65-66.

Burges, H.D and Jones K.A. (1998): Formulation of bacteria, viruses and protozoa to control insects. In: H.D. Burges (Ed.). Formulation of Microbial Biopesticides. pp 33127. Kluwer Academic Publishers, London

Martinez, A.M, Primitivo, C. and Trevor, W. (2004): Effects of an Optical Brightener on the development, body weight and sex ratio of Spodoptera frugiperda (Lepidoptera: Noctuidae). Biocontrol Sci. Technol. 14(2): 193-200.

Vigneshwaran, N., Kathe, A.A., Varadarajan, P.V., Nachane, R.O. and Balsubramanya, R.H. (2007): Functional finishing of cotton fabrics using silver nanoparticles. J. Nanosci. Nanotechnol. 7(6): 1893-1897.

Yaqoob, M., Arora, R.K. and Gupta, R.K. (2006): Estimation of resistance in Helicoverpa armigera (Hubner) to carbaryl and its effect on biology. Resist. Pest Manage. Newslett. $16: 18-32$. 